\title{
Anticlastogenic Effect of Euphorbia hirta using in vivo Rodent Micronucleus Assay
}

\author{
J. Ranjith*, P. Sriram, S. Ramesh, M. Parthiban, D. Sakthivel and Jangyadutta Dash \\ Department of Veterinary Pharmacology and Toxicology, Madras Veterinary College, \\ Chennai-600007, Tamil Nadu, India \\ *Corresponding author
}

\section{A B S T R A C T}

\section{Keywords}

Euphorbia hirta,

Anticlastogenicity,

Micronucleus assay, Mice

Article Info

Accepted:

25 May 2018

Available Online:

10 June 2018
Aqueous extracts of Euphorbia hirta were used to study the anticlastogenic activity by in vivo rodent micronucleus assay. Mice were administrated two doses, $250 \mathrm{mg} / \mathrm{kg}$ and $500 \mathrm{mg} / \mathrm{kg}$ orally for a period of seven days and at the end of the seventh day, cyclophosphamide $(50 \mathrm{~m} / \mathrm{kg})$ was given intraperitoneally. Bone marrow sample were analysed for cytotoxicity and micronucleus. Both the doses were not cytotoxic and clastogenic. There was a significant reduction in the micronucleus formation in bone marrow indicating the anticlastogenic activity of E. hirta.

\section{Introduction}

Euphorbia hirta (Tamil: Ammaan Pacharisi) is a common weed found in India, other tropical and subtropical countries. The plant has been used in traditional medicine to treat female disorders, respiratory ailments, especially cough, coryza, bronchitis and asthma, worm infestations in children and for dysentery, gonorrhoea, jaundice, pimples, digestive problems and tumours (Kirtikar et al., 1991). The phytochemical constituents may act as anticlastogenic agents which play a crucial role in prevention of cancer (Marmot et al., 2007). The current study was undertaken to evaluate the anticlastogenic effect of E. hirta using in vivo rodent bone marrow micronucleus assay.

\section{Materials and Methods}

Fetal calf serum (Himedia), Cyclophosphamide (Sigma-Aldrich), Methanol (Himedia), May Grunwald stain (Himedia) and Giemsa stain (Himedia) were used in this study. BALB/c mice (Mus musculus), Animals were housed six per cage and were acclimatized for one week at Centralized Laboratory Animal House, Madras Veterinary College, under controlled environment.

Commercial standard pellet diet and potable water were provided ad libitum. Thirty six male mice were divided randomly into six groups of six in each. The in vivo micronucleus procedure developed by Schmid 
(1975) was followed. The aqueous extract of E. hirta was administered at $250 \mathrm{mg} / \mathrm{kg} \mathrm{BW}$ (group 1 and 3) and $500 \mathrm{mg} / \mathrm{kg} \mathrm{BW}$ (group 2 and 4) for seven days. Negative control group was administered with normal saline alone for seven days. Positive control group and treatment group-3 and group-4 were administered with single dose of cyclophosphamide at $50 \mathrm{mg} / \mathrm{kg} \mathrm{BW}$ on $7^{\text {th }}$ day. After 24 and 48 hours of cyclophosphamide / normal saline administration, bone marrow were collected in fetal bovine serum for the micronucleus assay. The animals were anesthetized and killed by cervical dislocation. The femurs were removed and cleared of all attached tissues. Both the ends of the femur were cut to expose the bone marrow canal. Using fetal bovine serum, the bone marrow contents were flushed and collected in $2 \mathrm{ml}$ centrifuge tube. This suspension was centrifuged at $1000 \mathrm{rpm}$ for 10 min and the supernatant was discarded. The sediment was resuspended in $0.1 \mathrm{ml}$ of fetal bovine serum and this suspension was used to make smears on a microscopic glass slides andwere air dried. The air dried smears were then fixed in methanol for 5-10 min. For each animal, about three to four slides were prepared.

Air dried, methanol fixed slides were stained with undiluted May-Grunwald stain for $5 \mathrm{~min}$. Then slides were rinsed with distilled water for $2 \mathrm{~min}$. Then the slides were stained with $10 \%$ Giemsa stain for 9 min. Again the slides were rinsed with distilled water for $2 \mathrm{~min}$. The slides were air dried and observed in a microscope under oil immersion for micronucleus.2000 polychromatic erythrocytes per animal were analysed for the presence of micronucleus and 200 erythrocytes were analysed for the ratio of polychromatic erythrocytes to normochromatic erythrocytes to determine the cytotoxicity and the results were analysed using SPSS Statistics 17.

\section{Results and Discussion}

The two doses, $250 \mathrm{mg} / \mathrm{kg} \mathrm{BW}$ and $500 \mathrm{mg} / \mathrm{kg}$ BW of aqueous extract of E. hirta, administered orallydid not induce cytotoxicity as indicated by the ratio of PCE/NCE compared to the negative control group. Further there is no significant increase in the frequency of MNPCE compared to that of negative control (Table 1). The aqueous extract of E. hirta at $250 \mathrm{mg} / \mathrm{kg} \mathrm{BW}$ and $500 \mathrm{mg} / \mathrm{kg}$ BW showed significant dose dependent anticlastogenic activity at 24 and 48 hrs. There was a significant reduction in the micronucleus formation in bone marrow erythrocytes induced by the administration of cyclophosphamide $(50 \mathrm{mg} / \mathrm{kg}$ BW). Maximum inhibition was observed at $24 \mathrm{hrs}$ followed by $48 \mathrm{hrs}$ as shown in the Table 2. The present study indicates that the aqueous extract of E.hirta do not have any DNA damaging effect and it possess good DNA protective effect at the tested concentration. The aqueous extract of E. hirta showed excellent anticlastogenic activity against cyclophosphamide induced micronucleus formation in the erythrocytes, which acts by generation of free radicals that damage the DNA, RNA and proteins. The agents that has antioxidant properties acts as anticlastogens (Bronzetti et al., 2003). In this study, the aqueous extract of E. hirta was found to inhibit the micronucleus formation which can be attributed to antioxidant property of E. hirta (Sharma et al., 2008) (Subramanian et al., 2011). Similar results were obtained in in vivo micronucleus assay with plants like Boerhaviadiffusa by Ravichandra (2009), Tinosporacardifolia by Chandrasekaran (2005), Silymarin by Kaleeswaran (2006), Citral (Rabbani et al., 2005) which has excellent antioxidant properties. Rosmarinic acid revealed a significant reduction in micronucleus formation against DXR induced DNA damage which is attributed to the antioxidant activity by the phenolic compounds (Furtado et al., 2008). 
Table.1 Cytotoxic, clastogenic and anticlastogenic evaluation of Euphorbia hirta using rodent bone marrow micronucleus assay

\begin{tabular}{|c|c|c|c|c|c|}
\hline \multirow[t]{3}{*}{ Treatment } & \multirow{3}{*}{$\begin{array}{l}\text { Dose } \\
\text { (mg/kg) }\end{array}$} & \multicolumn{2}{|c|}{24 hours } & \multicolumn{2}{|c|}{48 hours } \\
\hline & & MNPCE$($ Mean \pm S.D $)$ & P/E RATIO & MNPCE(Mean \pm S.D) & P/E RATIO \\
\hline & & No. & & No. & \\
\hline $\mathbf{N C}$ & - & $6.33 \pm 1.52$ & $0.94 \pm 0.03$ & $7.66 \pm 1.15$ & $0.96 \pm 0.01$ \\
\hline $\mathbf{C P}$ & 50 & $49.66 \pm 3.50$ & $0.59 \pm 0.04$ & $28.00 \pm 3.50$ & $0.63 \pm 0.10$ \\
\hline Eh & 250 & $8.66 \pm 1.52$ & $0.92 \pm 0.01$ & $6.00 \pm 1.73$ & $0.93 \pm 0.01$ \\
\hline Eh & 500 & $10.00 \pm 1.00$ & $0.90 \pm 0.01$ & $6.66 \pm 1.52$ & $0.92 \pm 0.01$ \\
\hline $\mathrm{Eh}+\mathrm{CP}$ & $250+50$ & $20.00^{* *} \pm 2.08$ & $0.73 \pm 0.06$ & $12.66^{*} \pm 0.57$ & $0.77 \pm 0.12$ \\
\hline $\mathbf{E h}+\mathbf{C P}$ & $500+50$ & $16.66^{* *} \pm 3.05$ & $0.79 \pm 0.07$ & $11.00^{*} \pm 1.00$ & $0.81 \pm 0.01$ \\
\hline
\end{tabular}

NC- Negative control, Eh- Euphorbia hirta, CP- Cyclophosphamide, MNPCE- Micronucleated polychromatic erythrocytes, $\mathrm{P} / \mathrm{E}$ ratio- Polychromatic/Total erythrocyte ratio

** $\mathrm{P} \leq 0.01$ Significant at 1 percent, $* \mathrm{P} \leq 0.05$ Significant at 5 percent

The study has provided a further scope for evaluation of aqueous extract of E. hirta as a possible chemo prophylactic agent.

It was concluded that the aqueous extract of Euphorbia hirta was anticlastogenic at the dose tested which paves way for further studies to be used as chemotherapeutic agent.

\section{References}

Bronzetti, G., Cini, M., Caltavuturo, L., Fiorio, R. and Croce, C.D., 2003. Antimutagenictiy of sodium selenite in Chinese hamster V79 cells exposed to azoxymethane,

methylmethansulphonate and hydrogen peroxide. Mutat. Res., 523-524: 21-31.

Chandrasekaran, C.V., 2005. Studies on antimutagenic and anticlastogenic effect of Tinosporacordifolia. Thesis submitted to Tamilnadu Veterinary and Animal Sciences University, Chennai51.

Furtado, M.A., de Almeida, L.C.F., Furtado, R.A., Cunha, W.R. and Tavares, D.C., 2008. Antimutagenicity of rosmarinic acid in Swiss mice evaluated by the micronucleus assay. Mutation Research/Genetic Toxicology and
Environmental Mutagenesis, 657(2), pp. 150-154.

Kaleeswaran, S., 2006. Antimutagenic and anticlastogenic effects of Silymarin. Thesis submitted to Tamilnadu Veterinary and Animal Sciences University, Chennai-51.

Kirtikar, K.R. and Basu, B.D., 1991. Indian Medicinal Plants, Periodical Experts Books edition, Vol. 3, New Delhi.

Marmot, M., Atinmo, T., Byers, T., Chen, J., Hirohata, T., Jackson, A., James, W., Kolonel, L., Kumanyika, S., Leitzmann, C. and Mann, J., 2007. Food, nutrition, physical activity, and the prevention of cancer: a global perspective.

Rabbani, S.I., K. Devi and N. Zahra, 2005. Anti-clastogenic effects of citral. Iranian Journal of Pharmacology and Therapeutics, 41: 28-31.

Ravichandra, B.V., 2009. Exploration of in vitro and in vivo antimutagenic and anticlastogenic potentials of Boerhaaviadiffusa. Thesis submitted to Tamilnadu Veterinary and Animal Sciences University, Chennai-51.

Schmid W., 1975. The micronucleus test. Mutation research, 31: 9-15.

Sharma, N.K. and Prasad, R., 2008. Oxidative injury to protein and their protection by 
phenolic acid antioxidants from Euphorbia hirta leaves. Journal of Biotechnology, 136, p.S720.

Subramanian, S.P., Bhuvaneshwari, S. and Prasath, G.S., 2011. Antidiabetic and antioxidant potentials of Euphorbia hirta leaves extract studied in streptozotocininduced experimental diabetes in rats. General physiology and biophysics, 30(3), pp. 278-285.

\section{How to cite this article:}

Ranjith J., P. Sriram, S. Ramesh, M. Parthiban, D. Sakthivel and Jangyadutta Dash. 2018. Anticlastogenic Effect of Euphorbia hirta using in vivo Rodent Micronucleus Assay. Int.J.Curr.Microbiol.App.Sci. 7(06): 3790-3793. doi: https://doi.org/10.20546/ijcmas.2018.706.444 